\title{
Study of the genus Curcuma in Indonesia used as traditional herbal medicines
}

\author{
DYAH SUBOSITI", SLAMET WAHYONO \\ Medicinal Plant and Traditional Medicine Research and Development Center, National Institute Health Research and Development, Ministry of Health, \\ J1. Raya Lawu, Tawangmangu, Karanganyar 57792, Central Java, Indonesia. Tel./Fax. +62-271-697010, `email: dyah.subositi@ gmail.com
}

Manuscript received: 25 February 2019. Revision accepted: 25 April 2019.

\begin{abstract}
Subositi D, Wahyono S. 2019. Study of the genus Curcuma in Indonesia used as traditional herbal medicines. Biodiversitas 20: 1356-1361. Research into local knowledge is very important in providing a database of medicinal plants and as a basis for further research. The genus Curcuma (Zingiberaceae) has been used as medicines and other purposes, so it has a high economic value. The aim of this study was to record the use of the species of the genus Curcuma as traditional herbal medicines in Indonesia. The study was a part of a project called RISTOJA (Research on Medicinal Plants and Traditional Herbal Medicines), which collected data from 415 ethnic groups in Indonesia from 2012 to 2017. A purposive sampling method was used to select 2,354 respondents (traditional healers) for interviews, 1,042 of whom used Curcuma as herbal medicines. It was found that eight species of the genus were used to treat 73 different ailments. Curcuma longa was found to have the highest relative frequency of citation (0.274) and use value (0.563), and members of the genus Curcuma were found to be extensively used to treat a wide variety of ailments in Indonesia.
\end{abstract}

Keywords: Curcuma, ethnic groups, ethnomedicine, herbal medicines, Indonesia

\section{INTRODUCTION}

Indonesia has a high diversity of flora and fauna. Widjaja et al. (2014) reported that Indonesia has 1,500 algae species, 80,000 species of non-seed-bearing plants, and 30,000-40,000 species of vascular plants, constituting $15.5 \%$ of the total number of plant species in the world. Demographically, Indonesia has more than 1,300 ethnic groups and these groups vary in distribution and population size (Na'im and Syaputra 2011).

Knowledge of the use of medicinal plants is generally passed down orally from generation to generation. This method of transmission has weaknesses, such as limited memory, reduced understanding over time, and different oral traditions (Anisfiani et al. 2014). Knowledge of the use of plant species for treatment is most commonly held by traditional healers in a community (Awan et al. 2013). To prevent the loss of such knowledge as a result of modernization or other issues, this knowledge needs to be documented, and so ethnobotanical studies of the use of medicinal plants are needed (Amiri and Joharchi 2012). Through RISTOJA (an acronym for Riset Tumbuhan Obat dan Jamu, or Research on Medicinal Plants and Traditional Herbal Medicines), it is expected that databases of medicinal plants and their various uses in ethnic groups can be recorded and used both for the discovery of new active compounds and for the sustainable management of plant resources.

The use of plants in the treatment of various types of diseases has long been established, and each community involved has different knowledge about this type of use (Regina et al. 2015). Nowadays, medicinal plants are sources of new active compounds that have pharmacological and therapeutic effects, both when used directly and through various extraction processes. Active compounds in medicinal plants have been widely synthesized and used in modern medicines, with as much as $25 \%$ of medicines being derived from medicinal plant extracts (Khan et al. 2017).

The genus Curcuma is a member of the Zingiberaceae family and consists of about 80 species, mainly distributed across Southeast Asia, South Asia, and China. Several species of the genus Curcuma are also found in Australia and the southern Pacific region (Chen et al. 2013). India and Thailand have the highest Curcuma diversity of about 40 species (Leong-Skornickova et al. 2008). Some members of the genus have economic value, and are either cultivated commercially or planted as ornamental plants (Leong-Skornickova et al. 2008).

Indonesia is one of the countries with a high diversity of Curcuma species (Syamkumar 2008). Backer and Bakhuizen van den Brink (1968) reported 15 Curcuma species, including intraspecific taxa found in Java. These species include $C$. aurantiaca van Zijp, C. zedoaria (berg.) Roscoe, C. phaeocaulis Val., C. xanthorrhiza Roxb., $C$. aeruginosa Roxb., C. heyneana Val. \& v. Zijp, C. mangga Val., C. sylvatica Val., C. viridiflora Roxb., C. domestica Val., C. purpurascens B1., C. colorata Val., C. euchroma Val., C. brog Val., C. soloensis Val., and C. ochororhiza Val. More recently, a study by Nahar and Sarker (2007) reported species of the genus Curcuma found in Indonesia including $C$. aeruginosa Roxb., C. alismatifolia Gagnep, $C$. petiolata Roxb., C. phaeocaulis Valeton, C. rotunda L., and $C$. xanthorrhiza Roxb.

Curcuma is a herbaceous plant which has a pseudostem and forms a thick, fleshy rhizome. A compound 
flower appears at the end of the stem or arises separately from the rhizome. Internally, the rhizome varies in color from white, yellow, beige through orange, blue, bluish green and black (Sirigusa et al. 2007). Rhizomes are part of Curcuma most widely used as traditional ingredients, aroma enhancers, and natural dyes (Zhang et al. 2018).

Ethnobotanical studies carried out in Indonesia have mentioned the use of members of the genus Curcuma as medicinal plants used to treat various health problems and diseases; however, studies of the genus as used in traditional medicines by different ethnic groups in the country have not been widely carried out. The purpose of this study was to record the use of members of the genus Curcuma in traditional medicines in various ethnic groups in Indonesia.

\section{MATERIALS AND METHODS}

\section{Time and place}

This research used the data collected in studies carried out in 2012, 2015, and 2017 as parts of RISTOJA. The first was conducted in October and November 2012 and looked at 209 ethnic groups in 254 locations of 26 provinces throughout Indonesia (not including Java and Bali). Research into 96 ethnic groups in 100 locations of 24 provinces was carried out during August and September 2015, and 100 ethnic groups in 100 locations in 11 provinces in May 2017. These studies involved local researchers and local state universities.

\section{Sampling method}

Respondents were chosen using a purposive sampling approach based on information from indigenous community leaders, heads of villages, staff of health centers, and regional health offices. Respondents were traditional health healers (abbreviated in Indonesian as battra, i.e. pengobat tradisional) native to the local community who used plants as medicines. Five traditional healers were observed for each ethnic group.

\section{Data collection}

Data collection was conducted by interviews, observations, and documentation. Interviews were carried out using structured techniques to obtain as much information as possible on the use of plants in medicine. Activities were recorded by direct observation of respondents in the collection of ingredients (plants), preparation of herbal medicines, and treatment processes, both at collection and treatment locations. The recording was made in the form of notes, photos, audio, and video of all the processes and activities encountered during the research. Plants used by battra were then collected as voucher specimens and documented for the identification process. Voucher specimens were deposited at the Herbarium Tawangmanguensis (MPTMRDC). Data collected in RISTOJA were conditions treated by battra, species of medicinal plants, traditional medicinal ingredients, and local wisdom. But this study only used data of plant species belonging to the genus Curcuma and their utilization.

\section{Data analyses}

Data analyses were carried out descriptively and quantitatively for the species of Curcuma used, variety of uses, parts of plants used, methods of use, use value (UV), and relative frequency of citation (RFC). RFC is an indicator of the frequency of use of by respondents of Curcuma as ingredients for traditional medicines. It was calculated using the formula cited by Rehman et al. (2017):

$$
\begin{aligned}
& \text { RFC }=F C / N \\
& F C=\text { Number of respondents who mentioned the use of } \\
& \text { species in remedies } \\
& \mathrm{N}=\text { Total number of respondents interviewed }
\end{aligned}
$$

Use value was calculated to find out which species of plants have the highest use. It was calculated using the formula cited by Rehman et al. (2017):

$$
\begin{aligned}
& \mathrm{UV}=\mathrm{U} / \mathrm{n} \\
& \mathrm{UV}=\text { use value or species usability index } \\
& \mathrm{U}=\text { number of uses of one species } \\
& \mathrm{n} \quad=\text { number of respondents interviewed }
\end{aligned}
$$

\section{RESULTS AND DISCUSSION}

\section{The use of Curcuma in traditional medicines}

The results of the RISTOJA research showed that the total number of medicinal plant species used in 32,013 traditional medicine formulas was 2,848 , used by 2,354 respondents. Of these, eight species of the genus Curcuma were used as ingredients for traditional medicines, namely Curcuma aeruginosa Roxb., Curcuma caesia Roxb., Curcuma heyneana Valeton \& Zijp, Curcuma longa L., Curcuma manga Valeton \& Zijp, Curcuma rubescens Roxb., Curcuma zanthorrhiza Roxb., and Curcuma zedoaria (Christm.) Roscoe (Table 1).

A total of 2,031 traditional medicine formulas $(6.34 \%$ of the formulas identified) used species of Curcuma, with the pre- and postpartum conditions, gastritis, and liver disease being the most often treated conditions (Table 1). The Curcuma species the most widely used as herbal formulas was $C$. longa (1,326 formulas). Only four conditions that did not use $C$. longa, namely insect repellent, slimming treatment, epilepsy, and insomnia. However, C. longa was used to treat several conditions that did not use other Curcuma species, namely measles, herpes, mumps, contraception, nose bleed, dental and oral care, ear disease, and mental disorder. Curcuma caesia and $C$. rubescens were the least used by respondents; $C$. caesia was used to treat tumors and all diseases. Meanwhile, $C$. rubescens was used as an anti-toxin, for magical healing and spiritual properties, and also to treat all diseases. Curcuma zanthorrhiza was the only Curcuma species used as an herbal formula to treat epilepsy, while Curcuma sp. was the only one used to relieve insomnia (Table 1). 
Table 1. The number of respondents using Curcuma as traditional medicines for various health problems

\begin{tabular}{|c|c|c|c|c|c|c|c|c|c|}
\hline \multirow[b]{2}{*}{$\begin{array}{l}\text { Symptoms/ } \\
\text { diseases / } \\
\text { usages }\end{array}$} & \multicolumn{9}{|c|}{$\begin{array}{c}\text { Number of respondents using } \\
\text { Curcuma }\end{array}$} \\
\hline & 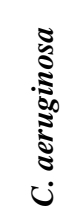 & 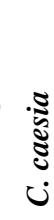 & 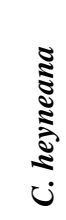 & $\frac{5}{3}$ & 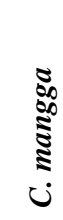 & 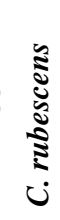 & 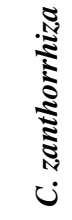 & : & 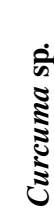 \\
\hline Tonsillitis & - & - & - & 4 & - & - & 1 & - & - \\
\hline Insect repellent & - & - & - & - & - & - & - & - & - \\
\hline Breast milk booster & 1 & - & - & 6 & - & & 4 & - & - \\
\hline Cough & 2 & - & - & 51 & - & & 3 & 3 & 3 \\
\hline Anti-inflammation & - & - & - & 8 & - & & 1 & 1 & - \\
\hline Dysentery & 1 & - & - & 9 & - & & 1 & - & - \\
\hline Slimming treatment & 1 & - & - & - & - & & 3 & 1 & - \\
\hline Smallpox & 1 & - & 1 & 28 & 1 & - & - & 1 & - \\
\hline Measles & - & - & - & 19 & - & - & - & - & - \\
\hline Bone pain & - & - & 1 & 46 & - & - & 4 & 3 & 3 \\
\hline Hypertension & - & - & - & 5 & 1 & - & 1 & - & 1 \\
\hline Fever & 2 & - & - & 41 & 2 & - & 5 & 5 & 3 \\
\hline Herpes & - & - & - & 2 & - & - & - & - & - \\
\hline Epilepsy & - & - & - & - & - & - & 2 & - & - \\
\hline Flu & - & - & - & 23 & 2 & - & 4 & - & 1 \\
\hline Diuretics & - & - & - & 6 & - & - & 1 & - & 1 \\
\hline Menstrual disorder & 1 & - & - & 28 & 2 & - & 1 & 2 & 2 \\
\hline Immunomodulator & 1 & - & - & 6 & - & - & 5 & 3 & 1 \\
\hline Fertility disorder & 1 & - & 1 & 14 & 3 & - & 5 & 1 & 2 \\
\hline Aphrodisiac & 1 & - & - & 14 & - & - & 2 & - & 1 \\
\hline Goiter & - & - & - & 5 & - & - & - & - & 1 \\
\hline Mumps & - & - & - & 2 & - & - & - & - & - \\
\hline Hernia & - & - & - & 5 & 1 & - & 1 & 1 & - \\
\hline HIV/AIDS & - & - & - & 3 & - & - & 1 & - & - \\
\hline Helminthiasis & 3 & - & - & 6 & - & - & - & 1 & 2 \\
\hline Muscle cramps & - & - & - & 8 & 1 & - & 1 & - & 2 \\
\hline Anti-diabetic & 7 & - & 1 & 21 & 2 & - & 11 & 3 & 6 \\
\hline Anti-toxic & 4 & - & - & 7 & 1 & 2 & 1 & - & 1 \\
\hline Hyperlipidemia & 1 & - & - & 4 & 3 & - & 4 & 2 & - \\
\hline Contraception & - & - & - & 4 & - & - & - & - & - \\
\hline Anti-anemia & - & - & - & 7 & - & - & 2 & 1 & - \\
\hline Appetite booster & 5 & - & - & 21 & 3 & - & 11 & 1 & - \\
\hline Healing fresh wounds & - & - & 1 & 35 & - & - & 1 & - & 1 \\
\hline Gastritis & 5 & - & 1 & 104 & 3 & - & 15 & 9 & 6 \\
\hline $\begin{array}{l}\text { Magical healing and } \\
\text { spiritual properties }\end{array}$ & 4 & - & - & 9 & - & 1 & - & 1 & 1 \\
\hline Malaria & 1 & - & - & 15 & - & - & 7 & 2 & 1 \\
\hline Diarrhea & 2 & - & - & 52 & 1 & - & 6 & 2 & 1 \\
\hline Nosebleed & - & - & - & 2 & - & - & - & - & - \\
\hline Sprue, sore throat & - & - & - & 10 & - & - & 2 & - & 1 \\
\hline Myalgia & 2 & - & - & 15 & 1 & - & 1 & 1 & 2 \\
\hline Swollen lymph nodes & 1 & - & - & 2 & - & - & 1 & - & 1 \\
\hline Venereal treatment & - & - & - & 20 & 1 & - & 1 & 5 & 2 \\
\hline Child health treatment & - & - & - & 18 & - & - & - & - & - \\
\hline $\begin{array}{l}\text { Neonatal treatment }(0- \\
<12 \text { months })\end{array}$ & - & - & - & 43 & - & - & 3 & 1 & 1 \\
\hline $\begin{array}{l}\text { Expectant mother } \\
\text { treatments }\end{array}$ & 1 & - & 1 & 2 & - & - & 3 & 1 & - \\
\hline Cosmetic & 2 & - & 2 & 15 & 1 & - & 3 & 1 & 1 \\
\hline Feminine care & 2 & - & 1 & 5 & 1 & - & - & 2 & - \\
\hline $\begin{array}{l}\text { Pre- and postpartum } \\
\text { treatments }\end{array}$ & 9 & - & - & 105 & 5 & - & 21 & 6 & 7 \\
\hline Rheumatics and gout & 3 & - & 1 & 10 & 6 & - & 9 & 4 & - \\
\hline Dental and oral care & - & - & - & 6 & - & - & - & - & - \\
\hline Heart disease & 1 & - & 1 & 9 & - & - & 4 & 2 & - \\
\hline
\end{tabular}

Headache

Skin disease

Liver disease

Eye care

Stomach ache

Kidney disorders

Ear disease

Constipation

Asthma

Mental disorders

Stroke

Insomnia

Tuberculosis

Typhus

Tumor/cancer

Appendicitis

Hemorrhoids

All diseases

Undefined diseases

Chronic kidney disease

Boils

Low blood pressure

Other internal diseases

Total

Table 2. Parts of plants used as traditional medicine formula

\begin{tabular}{|c|c|c|c|c|c|}
\hline \multirow[b]{2}{*}{ Species } & \multicolumn{5}{|c|}{ Part used $(\%)$} \\
\hline & 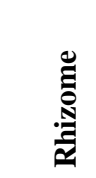 & ذ્ّ & E & $\frac{\bar{D}}{\bar{c}}$ & 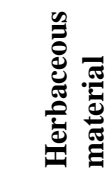 \\
\hline C. aeruginosa & 96.23 & 2.83 & - & 0.94 & - \\
\hline C. caesia & 100 & - & - & - & - \\
\hline C. heyneana & 100 & - & - & - & - \\
\hline C. longa & 94.08 & 5.69 & 0.08 & 0.08 & 0.08 \\
\hline C. mangga & 98.53 & 1.47 & - & - & - \\
\hline C. rubescens & 66.67 & - & - & 33.33 & - \\
\hline C. zanthorrhiza & 95.62 & 3.65 & - & - & 0.73 \\
\hline C. zedoaria & 97.54 & 1.64 & - & - & 0.82 \\
\hline Curcuma sp. & 94.68 & 5.32 & - & - & - \\
\hline Total & 94.81 & 4.79 & 0.08 & 0.15 & 0.20 \\
\hline
\end{tabular}

\section{Plant parts used and methods of usage}

Respondents of this research used five different parts of Curcuma. Rhizome was the most widely used part of the plant for traditional medicine formulas, followed by leaf (Table 2). Only the leaves of $C$. caesia, C. heyneana, and $C$. rubescens were not used in the herbal formula.

The flowers $(0.15 \%)$ of $C$. longa, C. aeruginosa, and $C$. rubescens and the stems $(0.08 \%)$ of $C$. longa were also used to make traditional medicines. Stems in the Zingiberaceae family are pseudo-stems composed of a collection of leaf midribs. Although these are actually part of the leaves, the information of Curcuma stem use in this research was separated from that of the leaves. Respondents also used herbaceous parts (all above-ground parts of plants, not separated into various parts such as leaf, stem, and flower) with a mean of $0.20 \%$ in $C$. longa, $C$. zanthorrhiza, and $C$. zedoaria. This shows that all parts of the three species were used to make traditional medicine formulas. 


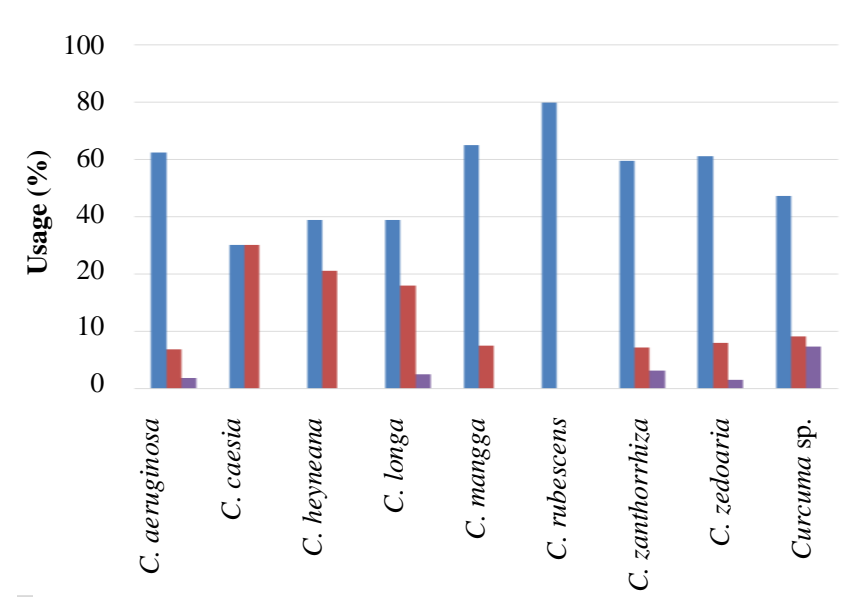

Curcuma spp.

Figure 1. Methods of usage of Curcuma in traditional medicines

Table 3. Total usage, use value, and relative frequency of citation of Curcuma species

\begin{tabular}{lrrrc}
\hline Species & $\begin{array}{l}\text { Total } \\
\text { usage }\end{array}$ & $\begin{array}{l}\text { Total } \\
\text { traditional } \\
\text { healers }\end{array}$ & $\begin{array}{l}\text { Use } \\
\text { value } \\
\text { (UV) }\end{array}$ & $\begin{array}{l}\text { Relative } \\
\text { frequency } \\
\text { of citation } \\
\text { (RFC) }\end{array}$ \\
\hline C. aeruginosa & 108 & 65 & 0.046 & 0.028 \\
C. caesia & 2 & 2 & 0.001 & 0.001 \\
C. heyneana & 18 & 13 & 0.008 & 0.006 \\
C. longa & 1,326 & 644 & 0.563 & 0.274 \\
C. mangga & 68 & 42 & 0.029 & 0.018 \\
C. rubescens & 4 & 2 & 0.002 & 0.001 \\
C. zanthorrhiza & 281 & 172 & 0.119 & 0.073 \\
C. zedoaria & 126 & 73 & 0.054 & 0.031 \\
Curcuma sp. & 98 & 59 & 0.042 & 0.025 \\
\hline
\end{tabular}

The efficacy of a plant is determined by its proper preparation and use. Methods of application of traditional medicine formulas made from Curcuma were classified into three: internal use, external use, and a combination of these two methods (Figure 1).

For internal use, most of the medicinal plants were given in the form of a drink with boiling or decoction commonly being done to prepare herbal formulas to treat diseases which generally originate from within the body. Externally, application of lotion, drops, and poultices and rubbing, massage, and compresses were the methods used to treat diseases affecting the outer organs (skin). Combination methods for internal and external preparations were also conducted, such as boiling the material in water for drinking and making it into lotion.

\section{Use value and relative frequency of citation}

The use of each species by respondents was shown by use value (UV) and relative frequency of citation (RFC) (Table 3).

The index of the use (UV) of Curcuma species ranged from 0.001 to 0.563 . Curcuma caesia had the lowest index of use while $C$. longa the highest. Curcuma longa also had the highest RFC, while $C$. caesia the lowest. This high RFC reflects the more frequent mention by respondents of C. longa being used in treatments. Parthiban et al. (2016) state that the RFC ranges from 0 to 1 , and that the higher the RFC value, the more frequently a species is used and better known by respondents.

\section{Discussions}

The genus Curcuma is a member of the Zingiberaceae family that has high economic and cultural values and is widely cultivated, used as a medicinal plant, planted ornamentally and is culturally important (Sathi 2017). Curcuma longa (turmeric) was the most widely used of the species in traditional medicinal formulas, with 1,326 instances of plants being used to treat 71 symptoms of disease (Table 1). This plant is a constituent of pre- and postpartum treatments, and treatments for gastritis, diarrhea, and stomach ache. Some ethnobotanical studies have reported similar usage of $C$. longa, for example in Kampar (Auliani et al. 2014) and Kuantan Singingi districts (Hartanto et al. 2014). Several studies have shown that $C$. longa can function as a hepatoprotector and can be used for the treatment of gastrointestinal and inflammatory diseases. The rhizome contains active compounds including curcumin, curcuminoid, dimethoxycurcumin, bisdemethoxycurcumin, and volatile oils (Bouzabata and Boukhari 2014).

Curcuma zedoaria was the most widely used species as a traditional medicinal remedy for tumors/cancer (Table 1). Several pre-clinical studies, both in vitro and in vivo, have demonstrated that $C$. zedoaria has an effect on tumors and cancer. The results of these studies include a decrease in tumor volume in mice injected with B16F10 melanoma cells (Carvalho et al. 2010), inhibition of B16 melanoma cell metastasis (Sao et al. 2005), strong anti-proliferative activity of MCF-7 breast cancer cells (Hamdi et al. 2014), and cytotoxicity effects on $\mathrm{SiHa}$ cervical cancer cells and HepG2 liver cancer cells (Kim et al. 2003). The active compounds isolated from $C$. zedoaria related to anti-tumor and cancer effects include $\alpha$-curcumin, isocurcumenol sesquiterpenes, curcuminoids, curzerenone, and alismol (Hadem and Sen 2017).

Curcuma caesia and C. rubescens were the least used species by respondents. This is probably due to the lack of documentation on the use of these less popular plants and the limited number of plants available because they are not cultivated by the communities. Curcuma caesia, which has bluish-black rhizomes, comes from central and northeastern India (Ravindran et al. 2007) while Curcuma rubescens is native to Bengal, Northeast India and Bangladesh and has dark-red stalks and leaf midribs (Ravindran et al. 2007). Treatment for tumors/cancers and use for all diseases were the two uses of $C$. caesia in ethnic Kolesusu (Southeast Sulawesi) and ethnic Duri (South Sulawesi). The part used was the rhizome, and the plant has a local name meaning 'black turmeric'. Bhutia and Sharangi (2017) report that C. caesia contains 30 chemical components, $97.48 \%$ in the form of the essential oils camphor, namely ar-turmerone, (z)-simene, archecumin, 
1,8-cineol, elemena, borneol, bornyl acetate, and curcumene. Empirical uses of $C$. caesia in India are similar to those found in Indonesia, including treatment of conditions including cancer, hemorrhoids, asthma, fever, wounds, vomiting, menstrual disorders, diarrhea, venereal disease, worms, and epilepsy and as stamina enhancers and anti-inflammatories (Das et al. 2013).

Curcuma rubescens is used by the Pasemah (Bengkulu) and Javanese (Yogyakarta) ethnic groups. Curcuma rubescens (local name means 'red turmeric') is used in the Pasemah tradition to treat poisoning and (magical) possession. Red turmeric is also the local name of $C$. rubescens in Javanese, in which tradition it is used to treat all diseases.

Rhizomes were the main part used on the Curcuma species as herbal material, probably because rhizomes are more available in amount than other parts, and also contain several secondary metabolites that have potential for medicine. Additionally, the flowers of $C$. aeruginosa, $C$. longa, and $C$. rubescens were also used in herbal remedies. Ming et al. (2002) reported that $C$. longa flower oils contained sesquiterpenoids (Zingiberene, $\beta$-sesquiphellandrene, $\beta$-caryophyllene, ar-curcumene, $\beta$-bisabolene (E)- $\beta$-farnesene) and monoterpenoids ( $85 \%)$ was the major constituents. Furthermore, the flowers of $C$. longa consist of a significant amount of curcumin and phenol content, which shows an antioxidant activity (Kumar et al. 2016). However, this is of concern to users because the generative phase (flowering) of Zingiberaceae is influenced by the season or month. Moreover, the formulas that use these ingredients cannot be made at other times and so substitute ingredients are sought.

Materials containing Curcuma as traditional medicines to treat several conditions could be made from single composition, mixture of different plant species, and also additive substance such as sugar, salt, minerals, etc. Internal usage or oral administration was the main method of usage in traditional medicine (Figure 1). Wildayati et al. (2016) report that the most widely used method of processing medicinal plants is boiling for use in drinks. The process chosen depends on the part of the plant used, with boiling generally used for stems and roots (rhizomes). Boiling is considered easier and more efficient than other methods and can be performed repeatedly to release active ingredients.

Eight species belonging to the genus Curcuma were used in traditional medicinal formulas in 415 ethnic groups in Indonesia. A total of 2,031 Curcuma plants were used to treat 73 types of disease. Curcuma longa (turmeric) had the highest UV and RFC. According to Shaheen et al. (2015), the higher the usability index value, the more important the species is in the population. Musa et al. (2011) state that the use value is dynamic and can change over time and it may decrease for some plants species due to different utilization preferences of each generation; it may also reflect difficulties in obtaining particular species. Plants species that have high UV values are the priority for further research, especially the study of active compounds and scientific evidence based on utilization data as traditional medicines. Curcuma caesia had the lowest UV and RFC
(Table 3). In addition, traditional knowledge about these species is at great risk of being lost because it may not be passed on to the next generation (Musa et al. 2011).

Information related to the use of Curcuma as a constituent of traditional herbal formula can be used to compile baseline data and for documenting the use of medicinal plants in Indonesia. The documentation of traditional knowledge of genus Curcuma in Indonesia has a great potential for further research especially to preclinical and clinical study validation on traditional usage and for new drug discovery.

\section{ACKNOWLEDGEMENTS}

This research is a further analysis of Medicinal Plant Research and Herbal Medicine (B2P2TOOT) Tawangmangu, Karanganyar, Indonesia. The author gratefully thanks the RISTOJA 2012-2017 research teams, the taxonomists who helped identify the specimens, and the Laboratory of Data Management, NIHRD-MOH, Indonesia for the subset data.

\section{REFERENCES}

Amiri MS, Joharchi MR. 2013. Ethnobotanical investigation of traditional medicinal plants commercialized in the markets of Mashhad, Iran. Avicenna J Phytomed 3 (3): 254-271

Anisfiani W, Asyiah IN, Hariani SA. 2014. Etnobotani bahan kosmetik oleh masyarakat Using Di Kabupaten Banyuwangi sebagai bahan ajar populer. Pancaran 3 (3): 53-62. [Indonesian]

Auliani A, Fitmawati, Sofiyani N. 2014. Studi Etnobotani Famili Zingiberaceae Dalam Kehidupan Masyarakat Lokal di Kecamatan Siak Hulu Kabupaten Kampar. JOM FMIPA 1 (2): 526-534. [Indonesian]

Awan ZI, Rehman H, Awan AA, Minhas FA, Khan MMN. 2013. Ethnobotanical Importance of Some Highly Medicinal plants of District Muzaffarabad, Pakistan with special reference to the Species of the Genus Viburnum. J Pharm Biol Sci 6 (2): 53-66.

Backer CAD. Sc, Bakhuizen van den Brink RC. 1968. Flora of Java (Spermatophytes only) Vol III, Wolters Noordoff, N.V. Groningen, The Netherlands.

Bhutia PH, Sharangi AB. 2017. Promising Curcuma species suitable for hill regions towards maintaining biodiversity. J Pharmacognosy and Phytochemistry, 6 (6): 726-731.

Bouzabata A, Boukhari A. 2014. Variation in the Traditional Knowledge of Curcuma longa L. in North-Eastern Algeria. International J Pharmacological and Pharmaceutical Sciences, 8 (11): 1227-1231.

Carvalho FR, Vasso RC, Nicoletti MA, Maria DA. 2010. Effect of Curcuma zedoaria crude extract against tumor progression and immunomodulation. J Venom Anim Toxins Incl Trop Dis, 16 (2): 324-341.

Chen J, Xia N, Zhao J, Chen J, Henny RJ. 2013. Chromosome Numbers and Ploidy Levels of Chinese Curcuma Species. Hortscience, 48 (5): 525-530.

Das S, Mondal P, Zaman MK. 2013. Curcuma Caesia Roxb. And It's Medicinal Uses: A Review. International J Research in Pharmacy and Chemistry, 3 (2): 370-375.

Hadem KLH, Sen A. 2017. Curcuma Species: A Source of Anticancer Drugs. J Tumor Medicine \& Prevention, 1 (5): 1-7.

Hamdi OAA, Rahman SNSA, Awang K, Wahab NA, Looi CY, Thomas NF, Abd Malek SN. 2014. Cytotoxic constituents from the rhizomes of Curcuma zedoaria. Scientific World Journal, 2014: 321943.

Hartanto S, Fitmawati, Sofiyani N. 2014. Studi Etnobotani Famili Zingiberaceae dalam Kehidupan Masyarakat Lokal di Kecamatan Pangean Kabupaten Kuantan Singingi, Riau. Biosaintifika, 6 (2): 122132. 
Kasarkar AR, Kulkarni DK. 2016. Traditional knowledge of medicines belonging to Family Zingiberaceae from South Western Maharashtra, India. International J Botany Studies, 1 (4): 20-23.

Khan I, Jan SA, Shinwari ZK, Ali M, Khan Y, Kumar T. 2017. Ethnobotany and medicinal uses of folklore medicinal plants belonging to family Acanthaceae: An updated review. MOJ Biology and Medicine, 1 (2): 34-38.

Kim MG, Kim JS, Hong JK, Ji MJ, Lee YK. 2003. Cytotoxic Activity of the Extracts from Curcuma zedoaria. J Toxicol Pub Health, 19 (4): 293-296.

Kumar A, Singh M, Singh PP, Singh SK, Raj P, Pandey KD. 2016. Antioxidant efficacy and curcumin content of Turmeric (Curcuma longa L.) Flower. Intl J Curr Pharmaceut Res 8 (3): 112-114

Leong-Skornikova J, Sida O, Marhold K. 2010. Back to types! Towards stability of names in Indian Curcuma L. (Zingiberaceae). Taxon 59 (1): 269-282

Ming CJ, Vera R, Chalchat JC, Cabassu P. 2002. Chemical composition of essential oils from rhizomes, leaves and flowers of Curcuma longa L. from Reunion Island. J Essent Oil Res, 1 (14): 249-51.

Musa MS, Abdelrasool FE, Elsheikh EA, Ahmed LAMN. 2011 Ethnobotanical study of medicinal plants in the Blue Nile State, South-eastern Sudan. J Medicinal Plants Research, 5 (17): 4287-4297.

Na'im A, Syaputra H. 2011. Kewarganegaraan, Suku Bangsa, Agama, Dan Bahasa Sehari-Hari Penduduk Indonesia Hasil Sensus Penduduk 2010. Badan Pusat Statistik. Jakarta. [Indonesian]

Partibhan R, Vijayakumar S, Prabhu S, Gnanaselvam J, Yabesh EM. 2016. Quantitative traditional knowledge of medicinal plants used to treat livestock diseases from Kudavasal taluk of Thiruvarur district, Tamil Nadu, India. Revista Brasileira de Farmacognosia 26 (2016): 109-121.

Ravindran PN, Babu KN, Sivaraman K (eds). 2007. Turmeric: The Genus Curcuma. CRC Press, Taylor \& Francis Group, New York
Regina KMM., Adama H, Jeanne M, Odile N. 2015. Ethnobotany and Ethnopharmacognosy of Lamiaceae Species from Central Burkina Faso: Leucas martinicensis (Jacquin) R. Brown, Hoslundia opposita Vahl and Orthosiphon pallidus Royle Ex Benth. American J Ethnomedicine, 2 (4): 219-232.

Rehmana MN, Ahmada M, Sultanaa S, Zafara M, Edward S. 2017. Original Article Relative popularity level of medicinal plants in Talagang, Punjab Province, Pakistan. Revista Brasileira de Farmacognosia, 27: 751-775.

Sathi AS. 2017. A review on pharmacological and cosmeceutical properties of Curcuma longa. Intl J Pharmaceut Sci Res 2 (1): 9-16.

Seo WG, Hwang JC, Kang SK, Jin UH, Suh SJ, Moon SK, Kim CH. 2005. Suppressive effect of Zedoariae rhizoma on pulmonary metastasis of B16 melanoma cells. J Ethnopharmacol 101 (3): 249257.

Shaheen H, Qureshi R, Qaseem MF. 2015. Qualitative investigation techniques used for analysis of ethnobotanical data from Thal Desert, Punjab Pakistan. J Med Plants Stud 3 (6): 69-75.

Sirirugsa P, Larsen K, Maknoi C. 2007. The genus Curcuma L. (Zingiberaceae): distribution and classification with reference to species diversity in Thailand. Gard Bull Sing 59 (2): 203- 220.

Syamkumar S. 2008. Molecular, Biochemical and morphological characterization of selected Curcuma accessions. [Th]esis. Indian Institute of Spices Research, University of Calicut, India.

Widjaja EA, Rahayuningsih Y, Rahajoe JS, Ubaidillah R, Maryanto I, Walujo EB, Semiadi G. 2014. Kekinian Keanekaragaman Hayati Indonesia. LIPI Press, Jakarta. [Indonesian]

Wildayati T, Lovadi I, Linda R. 2016. Etnomedisin penyakit dalam pada Suku Dayak Tabun di desa Sungai Areh Kecamatan Ketungau Tengah Kabupaten Sintang. Protobiont 4 (3): 1-7. [Indonesian]

Zhang L, Wei J, Yang Z, Chen F, Xian Q, Su P, Pan W, Zhang K, Zheng X, Du Z. 2018. Distribution and diversity of twelve Curcuma species in China. Nat Prod Res 32 (3): 327-330. 